\title{
Kriminalitetshyppigheden i Danmark
}

\author{
Foreløbig redegørelse for en empirisk undersøgelse \\ Af PREBEN WOLF, JAN KAARSEN og ERIK HøGH.
}

Måling af kriminalitetshyppigheden vil som oftest blive foretaget som mortalitetsunders $\varnothing$ gelse ved hjælp af den officielle kriminalstatistik. En beregning er fornylig foretaget af dr. jur. Karl O. Christiansen vedrørende mænd i de yngre aldersklasser. ${ }^{1}$ ) I $\varnothing$ vrigt skal om disse metoder og om anvendelse af kriminalstatistikken i det hele taget blot henvises til de i litteraturlisten anf $\varnothing \mathbf{r t}$ værker, der bl. a. også indeholder yderligere fyldige referencer til emnet. ${ }^{2}$ )

Forfatterne af denne artikel vil på ingen måde gøre sig til talsmænd for besværlige empiriske undersøgelser på områder, hvor man kan opnå samme resultat ved rigtig anvendelse af algebraisk metode. Da der imidlertid viste sig en mulighed for at sammenholde resultaterne af andre frekvensberegninger eller sk $\varnothing \mathrm{n}$ med empiriske fund, greb vi chancen.

Det ville dog være udtryk for dårlig forsknings $\varnothing$ konomi, hvis en sådan sammenligning skulle være det eneste formål med nærværende arbejde. Vi håber da også på at kunne komme adskilligt videre med vort materiale. Hvilke foreløbige resultater vi har nået, hvilke metoder vi har betjent os af, disse metoders fordele og mangler, og hvilke forventninger vi iøvrigt nærer til udfaldet af videre unders $\phi$ gelser af samme materiale skulle gerne fremgå af det følgende.

Arbejdet er fra planlæeggelsen til udarbejdelsen af denne artikel udf $\varnothing$ rt som et teamwork, hvor opgaverne har været fordelt snart på den ene, snart på den anden eller tredie, snart på to eller på alle tre forfattere $\mathrm{i}$ forening.

Der har ikke været særlige $\phi$ konomiske midler til rådighed for arbejdet; men vi skylder professor Kaare Svalastoga, direkt $\varnothing \mathrm{r}^{\circ}$ for fængselsvæsenet Hans Tetens og politiinspektør v. Magius megen tak fordi de - hver på sit felt - har bevirket, at unders $\varnothing$ gelsen overhovedet blev praktisk gennemførlig.

Det oprindelige materiale bestod af et tilfældigt udvalg af den danske folkeregisterbefolkning, omfattende ca. 6.000 mænd og kvinder fra 15-års alderen og opefter. ${ }^{3}$ )

Det endelige - repræsentative - udvalg blev indskrænket til 3032 mænd og 600 kvinder, der i 1954 var i alderen fra 21 år og derover. Disse mænd og kvinder er - med andre forskningsformål for $\emptyset$ je - undersøgt, herunder interviewet, således at en 
række sociologisk relevante faktorer er klarlagt for deres vedkommende.

Blandt de faktorer, som er oplyst i materialet, og som kan sættes i relation til kriminalitet, er følgende: Geografisk miljø og mobilitet, socialt miljø og mobilitet (såvel karriere som generationsmobilitet), familieforhold, erhverv, indtægt, formue, civilstand, uddannelse, omgangskreds, fritidsinteresse og fritidsanvendelse samt iøvrigt en række oplysninger vedrørende holdninger og indstillinger.

Det er vort håb, at vi senere vil kunne behandle en del af disse relationer og korrelationer til forekomsten af kriminalitet og ikke-kriminalitet.")

Hele det oprindelige materiale er gennemgået i rigsregistraturen og for de reldre årganges vedkommende (f $\phi \mathrm{dt} f \phi r$ 1918) tillige i Danske Politiefterretningers 5-årsregistre, derimod har det af praktisk-tekniske grunde endnu ikke været muligt at foretage en meget $\phi$ nskelig gennemgang af det ældre materiale i de lokale strafferegistre.

Samtlige de for de registrerede kriminelle eksisterende domsakter $m$. v. er derefter gennemgå t med henblik på fremskaffelse af f $\varnothing$ lgende oplysninger vedr. hver enkelt registrering for hver person:

1) Tidspunktet for dom i første instans, vedtagelse eller tiltalefrafald.

2) Alderen ved dette tidspunkt.

3) Sanktionens art og styrke (sidste instans).

4) Antal delikter.

5) Deliktets (ernes) art.

6) Hvor begået $o g$

7) Hvornår.

8) Ved hvilken underret (politikreds), sagen er behandlet.

9) Hvilken ret, der har afsagt endelig dom og hvornår.

10) Summarisk beskrivelse af forl $\phi$ bet af de anvendte indgreb (sanktioner).

Enkelte af disse punkter - navnlig punkt 10 - kræver gennemgang også af andre skriftlige kilder end doms- og politiakter, og disse yderligere unders $\phi$ gelser er endnu ikke afsluttet.

Ved registraturgennemgangen noteredes ikke blot straffelovsovertrædelser, men også særlovsovertrædelser, ikke blot domfældelser, men også vedtagelser, advarsler, tiltalefrafald og visse sluttede sager i $\phi$ vrigt.

Normalt vil man i kriminologiske arbejder vedrørende voksne personer være mere eller mindre bundet til ret snævre legalistiske definitioner ${ }^{4}$, hvorefter i Danmark kun overtrædelser af straffeloven og svangerskabsloven er kriminalitet og kun personer, der er $d \phi m t$ for straffelovs- eller svangerskabslovsovertræ- 
delser er kriminelle. I mange unders $\varnothing$ gelser vil disse definitioner være de videste, anvendelige operative definitioner, der bl. a. vil svare til kriminalstatistikkens (evt. dog med udeladelse af visse straffelovsovertrædelser, såsom betleri).

Her er vi gået videre, idet vi med tilslutning til synspunkter fremsat bl. a. af Edwin H. Sutherland, Marshall B. Clinard og Vilhelm Aubert ${ }^{5}$ ) har medtaget særlovgivningen. Vi er dernæst - måske til enkelte af vore juridiske kollegers forfærdelse gået uden for det strengt legalistiske og har medtaget sager, der vel er registrerede, men iklke gennemført på grund af bevisets stilling, privat påtalebegærings tilbagekaldelse, som bagatelsag eller i $\phi$ vrigt i medf $\varnothing r$ af det for anklagemyndigheden $i$ dansk retspleje gældende meget vide opportunitetsprincip. ${ }^{6}$ ) Rene frifindelser og henlaggelser, der er sket, fordi sigtelsen måtte anses for grundløs, er dog ikke medtaget.

Hermed mener vi at have defineret kriminalitet så vidt, som det har været operationelt muligt, nemlig som enhver af myndighederne (politiet) registreret konflikt med lovgivningens strafsanktionerede normer.

Medtagelsen af de sluttede sager betyder, at vi i tilslutning til Vilhelm Aubert, Verner Goldschmidt, Nils Christie o. $a .^{7}$ ) har inddraget retssociologiske aspekter i unders $\varnothing$ gelsen. I første omgang vil vi bl. a. kunne belyse omfanget af registrerede henlæggelser i forhold til antallet af sager gennemf $\varnothing \mathrm{rt}$ til dom, jfr. tabel II nedenfor, og dermed give en antydning af opportunitetsprincippets virkning.

Fordelene ved det anvendte materiale er, som det tildels vil være fremgåct af foranstående, at materialet er repræsentativt for den voksne danske befolkning 1954 , d. v. s. samme år som danner udgangspunkt for Karl O. Christiansens og Arne Nielsens beregning af kriminalitetshyppigheden pr. år for de ,store årgange". ${ }^{1}$ ) Endvidere at materialet er kortlagt og unders $\varnothing$ gt på en række andre områder end det kriminologiske, men med hensyn til faktorer, der må antages at være relevante også i kriminologisk henseende.

Ulemperne er, dels at man har måttet anvende et materiale, der er tilvejebragt med ikke-kriminologisk formål for $\varnothing$ je, dels at det er for lille til, at man med større held kan opdele det i så mange kategorier, som det egentlig ville være $\varnothing$ nskeligt, navnlig vil det blive vanskeligt at få en tilfredsstillende findeling efter forbrydelsesarter.

Mørketallets problemer har vi naturligvis ikke $l \varnothing$ st, men vi har ved at gå ud over straffelovens snævre kriminalitetsdefinition, ved at medtage de sluttede sager og særlovsovertrædelserne ment at kunne kaste yderligere lys over omfanget af lovovertrædelsernes problem i Danmark. 
Da rigsregistraturens ${ }^{*}$ ) oplysninger om lovovertrædelser begået $\mathrm{f} \phi \mathrm{r} 1933$ (straffelovens ikrafttrædelsesår) ikke er fuldt pålidelige, må de frekvenstal, der er fundet i nærværende arbejde, betragtes som minimumstal, idet man ikke har sikkerhed for, at alle registrerede er med. Det er nemlig givet, at nogle af de ældre lovovertrædere samt en række af bagatelforseelserne, der er endt med bøder eller advarsler, enten slet ikke er registreret eller kun registreret lokalt. Det er således værd at notere, at der i hele materialet ikke findes nogen bøde for ulovlig parkering eller kørsel uden cyklelygte, cyklek $\phi$ rsel på fortovet, overgang mod r $\varnothing \mathrm{dt}$ lys, ikke-benyttelse af fodgængerovergang etc. Det er i det hele motork $\phi$ rerne, der præger de registrerede færdselsovertrædelser. Derimod findes der en del politivedtægtsovertrædelser, navnlig b $\phi d e r$ for at have været til ulempe for andre på grund af beruselse, husspektakler o. lign. I hele materialet findes kun en enkelt bøde for overtrædelse af brandpolitiloven, en del kriselovsovertrædelser (som regel af større omfang eller grovere karakter) fra perioden under og efter den anden verdenskrig, men f. eks. ingen „,klausulædere“ fra den første verdenskrig eller tiden umiddelbart derefter. Det er et skønsspørgsmål, hvad man vil kalde bagatelforseelser, men der findes en lang række småforseelser (der formentlig er særdeles hyppige), som ikke registreres centralt, og som altså heller ikke medvirker til at bringe vore frekvenstal i vejret.

Hvis nogle skulle synes, at vi hænger os i bagateller i opgørelsen af kriminalitetshyppigheden, så må de trøste sig med, at der er endnu mindre bagateller, som altså ikke er med i tallene.

Med de i det foregående nævnte begrænsninger kan vi i denne unders $\varnothing$ gelse oplyse, hvor stor en procentdel af den voksne danske befolkning, der er registreret i anledning af en eller flere lovovertrædelser, hvor mange der kun har sager, som er sluttet uden nogen form for sanktion, hvor mange der er registreret i anledning af straffelovsovertrædelser, og hvor mange der er registreret for særlovsovertrædelser og kun særlovsovertrædelser.

I det efterfølgende vil vi koncentrere os om mændene - da kvinderne er så få, at det ikke vil være muligt at foretage statistisk bearbejdelse af dette materiale. Det skal dog oplyses, at vi fandt $2.3 \%$ kriminelle kvinder $\bmod 18,8 \%$ kriminelle mænd for hele landet.

For mændenes vedkommende er frekvensen opgjort for land og by i nedenstående tabel $I$, idet kriminalitet, for ikke at støde læsere, som måtte være uenige $\mathrm{i}$ vor vide definition af dette begreb, er erstattet med ordet konflikt. I yderste venstre kolonne

*) Den drøftelse af registreringsregler og registreringspraksis, som det ville være naturligt at medtage $i$ en mere udførlig behandling af emnet, har forfatterne betragtet som liggende uden for rammerne af denne foreløbige redeg $\phi$ relse. 
er anf $\phi r^{2} 5$ urbaniseringsgrader fra storby (hovedstaden) over st $\varnothing \mathrm{rre}$ og mindre $\mathrm{k} \phi$ bstæder og bebyggelser til rene landdistrikter og bebyggelser med mindre end 2.000 indbyggere.

Tabel I.

\begin{tabular}{|c|c|c|c|c|c|c|}
\hline Urbaniseringsgrad & & nflikt & $\mathrm{Ej}$ & onflikt & & otal \\
\hline $\begin{array}{l}\text { Kbhvn. + Frdb.: } \\
\text { Kbhvns. Omegn: }\end{array}$ & & & & & & \\
\hline Hovedstaden: & 215 & $25,7 \%$ & 621 & $74,3 \%$ & 836 & $100 \%$ \\
\hline Byer m. $100.000+$ indb. & 44 & $22,7 \%$ & 150 & $77,3 \%$ & 194 & $100 \%$ \\
\hline$" \quad, 20-99.000 \quad$, & 88 & $26,1 \%$ & 249 & $73,9 \%$ & 337 & $100 \%$ \\
\hline Landdistr $2-19.000$ " & 61 & $17,4 \%$ & 290 & $82,6 \%$ & 351 & $100 \%$ \\
\hline under 2000 indb. & 161 & $12,3 \%$ & 1152 & $87,7 \%$ & 1313 & $100 \%$ \\
\hline Total & 569 & $18,8 \%$ & 2462 & $81,2 \%$ & 3031 & $100 \%$ \\
\hline
\end{tabular}

Det fremgår af tabel $I$, at først ved byer med under 20.000 indbyggere, kan man se det fald i konfliktfrekvensen, som man skulle forvente ville finde sted med faldende urbaniseringsgrad. Byer med 20.000 indbyggere og derover har en konfliktfrekvens på mellem 23 og $26 \%$, byer mellem 2 og 19.000 indbyggere har en konfliktfrekvens på $17 \%$, medens landdistrikter og byer med mindre end 2.000 indbyggere har en konfliktfrekvens på $12 \%$.

For læsere, der interesserer sig specielt for straffelovsovertrædelsernes fordeling efter urbaniseringsgrad, har vi i tabel II op-

Tabel II. Antallet af personer, der har overtrådt straffeloven og særlovgivningen, men ikke straffeloven, og som har registrerede, men kun sluttede sager, fordelt pai by og land.

\begin{tabular}{|c|c|c|c|c|c|c|c|c|}
\hline \multirow{2}{*}{$\begin{array}{l}\text { Urbaniseringsgr } \\
\text { Hovedstaden: }\end{array}$} & \multicolumn{2}{|c|}{$\begin{array}{l}\text { Straffe- } \\
\text { lovs- } \\
\text { overtr. }\end{array}$} & \multicolumn{2}{|c|}{$\begin{array}{l}\text { Sær- } \\
\text { lovs- } \\
\text { overtr. }\end{array}$} & \multicolumn{2}{|c|}{ Total } & \multicolumn{2}{|c|}{$\begin{array}{c}\text { Heraf } \\
\text { kun slut. } \\
\text { sager: }\end{array}$} \\
\hline & & & & & & & & \\
\hline Kbhvn. + Frdb. & 93 & $54 \%$ & 80 & $46 \%$ & 173 & $100 \%$ & 18 & $10 \%$ \\
\hline Københavns Omegn & 16 & 38 & 26 & $62 \%$ & 42 & $100 \%$ & 5 & $12 \%$ \\
\hline Byer m. $100.000+$ indb. & 24 & $55 \%$ & 20 & 45 & 44 & $100 \%$ & 4 & $9 \%$ \\
\hline$" \quad 20-99.000$ & 46 & 52 & 42 & 48 & 88 & 10 & 12 & $14 \%$ \\
\hline$" \quad, \quad 2-19.000$ & 31 & $51 \%$ & 30 & $49 \%$ & 61 & $100 \%$ & 7 & $11 \%$ \\
\hline $\begin{array}{l}\text { Landdistr. og byer } \mathrm{m} \text {. } \\
\text { under } 2.000 \text { indb. }\end{array}$ & 82 & $51 \%$ & 79 & $49 \%$ & 161 & $100 \%$ & 17 & $11 \%$ \\
\hline Total & 292 & $51 \%$ & 277 & $49 \%$ & 569 & $100 \%$ & 63 & $11 \%$ \\
\hline
\end{tabular}


delt konflikterne i straffelovsovertrædelser og særlovsovertrædelser og fordelt begge konfliktformer efter urbaniseringsgrad.

Der synes at være en tendens til relativt flere straffelovsovertrædelser og færre henlæggelser i de store byer. Den lave andel af straffelovsovertrædere i Københavns omegnskommuner hænger formentlig sammen med, at disse distrikters befolkning overvejende $\mathrm{h} \phi \mathrm{rer}$ til de mere velstillede, højere statuslag. ${ }^{9}$ )

Hvis der skal drages sammenligninger med andre frekvensberegninger, må man se bort fra henlæggelserne og særlovsovertrædelserne, idet de i indledningen omtalte snævrere kriminalitetsdefinitioner altid må anvendes, når man er nødt til at støtte sig på den officielle kriminalstatistik. Hvis vi således trækker totaltallet $\mathrm{i}$ tabel II's sidste kolonne fra næstsidste kolonne, får vi et totalantal kriminelle på 506 personer svarende til 16,7 \% af hele befolkningen. $\mathrm{Nu}$ fordeler særlovs- og straffelovsovertrædelserne sig ikke ligeligt på de sluttede sager, idet der antagelig henlægges flere sager for overtrædelse af særlovgivningen end for overtrædelser af straffeloven, men da vi ikke har opgjort dette nøjagtigt, så lad os blot antage, at de fordeler sig med $50 \%$ til hver. Dette vil give $8,6 \%$ kriminelle i traditionel forstand, hvilket svarer meget godt til den hidtil gældende opfattelse, således har f. eks. Lauge R. Kallestrup beregnet frekvensen til $8 \%{ }^{\mathrm{s}}$ ). Karl O. Christiansen regner, efter hvad der er oplyst for os, med noget lignende.

Til belysning af opportunitetsprincippets anvendelse i dansk retspleje kan foranstående tabel ikke bidrage noget udover, at man synes at kunne regne med, at omkring $10 \%$ af samtlige personer med registrerede sigtelser, der ikke udtrykkeligt er betegnet som fuldstændig grundløse - hvad de meget sjældent er - slipper med henlæggelse uden tiltale på grund af bevisets stilling etc. Tiltalefrafald i medf $\phi r$ af straffelovens $\S 30$ eller forsorgslovens $\S 150 \mathrm{mod}$ inddragelse under børneforsorg er ikke her betragtet som sluttede sager. Preben Wolf, Jan Kaarsen, Erik Hфgh.

\section{LITTERATURLISTE.}

1. Karl O. Christiansen i samarbejde med cand, act. Arne Nielsen: Den forventede kriminalitet i de store fødselsårgange. N.T.f.K. 1958. 1. hft. p. 4 ff.

2. Stephan Hurwitz: Kriminologi, Kbhvn. 1951. P. $27 \mathrm{ff}$.

Edwin Sutherland \& D. R. Cressey: Principles of Criminology. 5. udg. N. Y. 1955. Pp. 25-50.

Maths Heuman \& Sven Rengby: Kriminalstatistikken i Ivar Agge m. fl. Kriminologi, Stockholm 1955.

Gunnar Dahlberg \& Torgny Lindberg: Om frekvensen av atterfall i brott. Bil. 3 til Strafflagberedningens Betänkande ang. Verkställigheten av Frihetsstraff m. m. S.O.U. 1944-50. 
3. Kaare Svalastoga: Prestige, Class and Occupation. Forthcoming publication 1958. Jfr. også Erik Høgh: Sociologi I og II, Kbhvn. 1957.

4. Om kriminalitetsdefinitioner, se bl. a. Hurwitz op.cit. og samme: Den danske kriminalret, alm. del, 1. hft. Kbhvn. 1950. Den danske kriminale
Sutherland op.cit., Agge op.cit., Johs. Andenæs: Alminnelig StraffeCongress of Criminology, sect. I, 1955, London 1957 og N.T.f.K. 4. hft. 1957 , p. 400 , note 2.

5. Sutherland, op.cit. Vilh. Aubert: Om Straffens sosiale Funksjon. Oslo 1954. Marshall B. Clinard: Sociology of Deviant Behaviour, part 2. N.Y. 1957.

6. Stephan Hurwitz: Den danske Strafferetspleje. Kbhvn. 1949.

7. Aubert op.cit. Verner Goldschmidt: Retlig adfærd. Kbhvn. 1957. Nils Christie: Utrykt diskussionsindlæg til Lillehammermødet. 1958.

8. Lauge $R$. Kallestrup: Straffefrekvensen i forskellige sociale grupper. N.T.f.K. 1954, pag. $30 \mathrm{ff}$.

9. Erik Høgh \& Preben Wolf: Kriminalitetsfrekvens II: Kriminalitetsfrekvens, Social Konflikt og Social Klasse,
Utrykt indlæg til Lillehammermødet 1958. 